\title{
Emergency Response Principles of Typhoon Disaster
}

\author{
Yiwan Wang \\ School of Public Administration and Emergency Management, Jinan University, Guangzhou, China \\ Email: ywwang9@163.com
}

How to cite this paper: Wang, Y.W. (2017) Emergency Response Principles of Typhoon Disaster. Open Journal of Social Sciences, 5, 100-104.

http://dx.doi.org/10.4236/jss.2017.51008

Received: December 15, 2016

Accepted: January 10, 2017

Published: January 13, 2017

Copyright (C) 2017 by author and Scientific Research Publishing Inc. This work is licensed under the Creative Commons Attribution International License (CC BY 4.0).

http://creativecommons.org/licenses/by/4.0/

\begin{abstract}
Since 2003, China has made extraordinary achievements in emergency management, and successfully dealt with a large number of unexpected events, especially meteorological disasters. At the same time, a complete system of emergency laws, regulations and plans are gradually established. Through reviewing those official documents, this paper finds out four important principles that typhoon disaster emergency responses follows: warning level based, disaster consequences and types oriented, unified leadership and departmental response, decentralized response and localized management.
\end{abstract}

\section{Keywords}

Typhoon Disaster, Warning Level Based, Consequences and Types Oriented, Unified Leadership and Departmental Response, Decentralized Response and Localized Management

\section{Introduction}

Typhoon disaster is a natural disaster that refers to the formation of tropical and Subtropical Ocean cyclonic eddies in a wide range of activities with strong wind, rainstorm, storm tide and waves, which may cause damage to human life and properties $^{1}$. Along with the occurrence of natural disasters, a series of other disasters often followed. This phenomenon is called disaster chain. Within disaster chain, the earliest disasters are named primary disasters, which may lead to secondary disasters. And when the harmonious condition of human existence is disrupted and a series of other disasters aroused, derivative disasters appear. Typhoon disasters often lead to a series of secondary and derivative disasters, such as debris flow, flood and disease.

Since 2010, China Meteorological Bureau has started various meteorological

${ }^{1}$ Natural Disasters Losses Statistical System, 5 Ministry of Civil Affairs (2008). 
disasters emergency responses for more than 70 times, such as typhoon, heavy rain and other extreme weather phenomena, amounting to 362 days [1]. Succeeding in dealing with more than 60 typhoons, like "Swallow" and "Nida", and more than 20 times heavy rainstorms, these emergency responses played an important role in reducing the negative impact on the economic and social development efficiently and effectively. Since then, such a great success has been made. So, what kind of response system does State of China has established? What principles does China's meteorological disaster emergency response base on?

\section{Establishment of Meteorological Disasters Response Mechanism in China}

Since 2003, China has been through Bird Flu, Wen Chuan Earthquake and other public emergencies, which highlights the importance of public emergency management. In January 2006, the State Council issued the National Emergency Plan. It defines Public Emergencies as emergencies that suddenly cause or may cause heavy casualties, property loss, destruction of the ecological environment and serious social harms, which would endanger public safety ${ }^{2}$. The public emergencies were divided into four categories: natural disasters, accidents, public health incidents and social security incidents. According to the degree of harm and urgency, and as well as development trend, they are also classified into four levels as Level I (extremely serious), Level II (serious), Level III (slightly serious), and Level IV (generally serious).

On the basis of National Emergency Plan, 25 Special Emergency Plans and 80 Government Departmental Emergency Plans have been established, including a series of Meteorological Disaster Emergency Plans. Since 2010, 31 provinces, $95 \%$ of the Municipal governments and more than 2200 county-level governments formulated the Special Emergency Plan for meteorological disasters. Additionally, a big progress has been made by meteorological departments at all levels which make Meteorological Disaster Plan system more adequate and efficient. Meteorological Bureau has made 5 pieces of meteorological disaster plans, subordinate departments for 71 pieces, the provincial bureaus for 306 pieces, and county meteorological departments for more than 6000 pieces.

The establishment of Meteorological Disaster Plan system marks the initial establishment of China's emergency response mechanism for meteorological disasters, including typhoon disasters.

\section{Principles of Typhoon Disaster Response}

China is one of the countries that suffer from natural disasters most frequently in the world, of which meteorological disasters accounts for more than $70 \%$. As the government with the richest experience, Chinese government mainly divides meteorological disaster response level into four as Level IV to Level I. When a strong typhoon, or a super typhoon is expected to land or impact coastal areas in the future, the national meteorological department will launch Level I typhoon

${ }^{2}$ National Emergency Plan, The Central People's Government of China (2006). 
disaster response, marked as Red; when a tropical storm is around the corner, a Blue emergency response will be issued which means Level IV (as shown in Table 1).

\subsection{Warning Level Based}

Chinese government and its functional departments mainly determine the major meteorological disaster response level by the results monitored and forecast by Central Meteorological Observatory [2]. Conventionally, the results will be showed as Warning Signals. According to the approximation of landing time and intensity, Central Meteorological Observatory generally divides the early warning signal into four levels (IV, III, II, I), represented separately by blue, yellow, orange and red (as shown in Table 1).

If more than one meteorological disasters occur at the same time, several warning signals would be issued ${ }^{3}$. Additionally, when there are more than two kinds of meteorological disasters going to occur and the different levels of warning signals have been released, emergency response would be started according to the highest warning level.

\subsection{Disaster Consequences and Types Oriented}

According to National Meteorological Disaster Emergency Plan, the authorities should launch the emergency response in accordance with disaster influence, as well as the secondary and derivative disasters it causes. This laid the basic principle of emergency response mechanism, namely, the disaster consequences and types oriented principle. With wind and rain, storm surges and other weather phenomena, typhoon makes people unable to carry out routine production activities and lead a usual life. Meanwhile, it also could cause floods, landslides and debris flows and other geological disasters. There exists a great possibility for typhoon to arouse disease and other derivative disasters. According to the types of Typhoon's secondary and derivative disasters, there are always several responses would be issued, which is given to considered in Meteorological Disaster Emergency Plan (shown in Table 2).

Table 1. Typhoon warning and response level.

\begin{tabular}{cll}
\hline Warning Level & Color & Meaning \\
\hline Level IV & Blue & $\begin{array}{l}\text { May or have been affected by tropical storm within } 24 \text { hours, } \\
\text { the average wind above Level } 6 \text { in coastal areas or the mainland }\end{array}$ \\
Level III & Yellow & $\begin{array}{l}\text { May or have been affected by tropical storm within } 24 \text { hours, } \\
\text { the average wind above Level } 10 \text { in coastal areas or the mainland } \\
\text { Level II }\end{array}$ \\
Orange & $\begin{array}{l}\text { May or have been affected by tropical storm within } 12 \text { hours, } \\
\text { the average wind above Level } 10 \text { in coastal areas or the mainland } \\
\text { Revel I }\end{array}$ & $\begin{array}{l}\text { May or have been affected by tropical storm within } 6 \text { hours, } \\
\text { the average wind above Level } 12 \text { in coastal areas or the mainland }\end{array}$ \\
\hline
\end{tabular}

Source: Trial Measures for the Release of Early Warning Signals of Meteorological Disasters.

${ }^{3}$ Trial Measures for the Release of Early Warning Signals of Meteorological Disasters, China Meteorological Administration (2008). 
Table 2. Emergency plan related to typhoon disaster.

\begin{tabular}{|c|c|c|}
\hline Consequences & Response Department & Types of Emergency Plan \\
\hline $\begin{array}{l}\text { Causing mass casualties or may lead } \\
\text { to sudden public health events }\end{array}$ & Ministry of Health & $\begin{array}{l}\text { National Public Health and Medical Emergency plan } \\
\text { National Health Emergency Plan for Natural Disasters }\end{array}$ \\
\hline Causing geological hazards & Ministry of Land and Resources & National Plan for Environmental Emergencies \\
\hline $\begin{array}{l}\text { Causing danger to marine vessels and } \\
\text { the pollution of the oil spill }\end{array}$ & Ministry of transportation & $\begin{array}{l}\text { National Maritime Search and Rescue Plan } \\
\text { China Offshore Oil Spill Emergency Plan }\end{array}$ \\
\hline Causing floods & Departments responsible for Anti-floods & State Flood Control and Drought Relief Emergency Plan \\
\hline Causing city floods & $\begin{array}{l}\text { Ministry of Housing and } \\
\text { Urban Construction }\end{array}$ & \\
\hline Causing agricultural losses & Ministry of Agriculture & $\begin{array}{l}\text { Major Agriculture Disasters Emergency Plan } \\
\text { Fishery Ship Safety Emergency Plan }\end{array}$ \\
\hline causing marine disasters & Marine Department & $\begin{array}{l}\text { Storm surge, Waves, Tsunamis and Sea ice } \\
\text { Disaster Emergency plan }\end{array}$ \\
\hline need for emergency life assistance & Ministry of Civil Affairs & National natural disaster relief emergency plan \\
\hline
\end{tabular}

Source: Meteorological Disaster Emergency Plan.

\subsection{Unified Leadership and Departmental Response}

The meteorological disaster response mechanism is closely related to the linear function leadership structure of the government in China. The State Council is the highest administrative institution of meteorological disasters management. Departments under the State Council are in charged of the relevant categories of public emergency management work in accordance with the relevant laws, administrative regulations and their respective duties. Provincial government agencies have the same leadership structures with central government and similar administrative power and responsibilities. Local governments are responsible for all kinds of meteorological disasters in the administrative area, and government departments should start Departmental and Special Plans on their duties.

\subsection{Decentralized Response and Localized Management}

China's existing Plan system is an across-the-aboard emergency plan system [3]. Meteorological disaster emergency plan itself is also with multi-classes network structures (as shown in Figure 1). According to the influence of meteorological disasters, the response can be divided into national and local level. When disasters are among provincial administrative regions, and will cause huge losses, it is the State Council that decides which emergency response level to start. When the impact is within a province, the local provincial governments will be in charge. After the occurrence of meteorological disasters, the provincial governments shall start the relevant emergency plans and take effective disposal to control the situation at the first time. If they fail, the State Council, then, will take control.

\section{Conclusion}

After the emergency occurs, the emergency response should be launched in time. 


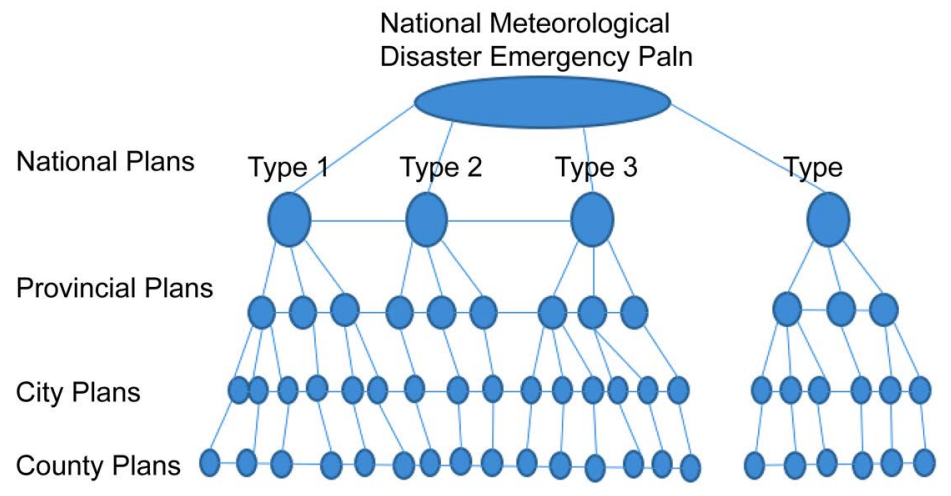

Figure 1. Meteorological disaster emergency plan system.

The start of the emergency response is not without rules; it follows certain principles. The start of the emergency response not only needs to be based on the actual disaster information, negative influence and great losses it may cause, but also needs to be combined with the existing political system and institutional functions of our country. Therefore, by reviewing the Meteorological Law of People's Republic of China, China Meteorological Disaster Emergency Plan and other relevant laws and regulations, this article outlines emergency response basis and principles of typhoon disaster, through which, it may provide some help for readers to have a better understanding of typhoon emergency response system in China.

\section{References}

[1] Xu, X.F. (2015) Implementation Effect and Thinking of National Meteorological Disaster Emergency Plan. China Emergency Management, 3, 6-10.

[2] China Meteorological Administration (2010) Grade of Severe Meteorological Disaster Emergency Response. Beijing Jingke Printing Corporation, Beijing, 21.

[3] Wang, J. and Rong, L.L. (2015) Disaster Consequences-Oriented Start-Up Mode of Emergency Plan System. Journal of Natural Disasters, 3, 1-11.

Submit or recommend next manuscript to SCIRP and we will provide best service for you:

Accepting pre-submission inquiries through Email, Facebook, LinkedIn, Twitter, etc. A wide selection of journals (inclusive of 9 subjects, more than 200 journals)

Providing 24-hour high-quality service

User-friendly online submission system

Fair and swift peer-review system

Efficient typesetting and proofreading procedure

Display of the result of downloads and visits, as well as the number of cited articles

Maximum dissemination of your research work

Submit your manuscript at: http://papersubmission.scirp.org/

Orcontact jss@scirp.org 